\title{
PENGARUH TEKNIK RELAKSASI GENGGAM JARI TERHADAP INTENSITAS NYERI PADA PASIEN POST SECTIO CAESAREA DI RSUD ARIFIN ACHMAD PROVINSI RIAU
}

\author{
${ }^{(1)}$ Ani Laila, ${ }^{(2)}$ Yessi Novita, ${ }^{(3)}$ Yan Sartika ${ }^{(4)}$ Ari Susanti \\ Prodi D III Kebidanan, Poltekkes Kemenkes Riau Pekanbaru \\ J1. Melur no. 103 Sukajadi Pekanbaru-Riau-Indonesia \\ Email : ani.laila1978@gmail.com, yesiyesi405@gmail.com, yansartika1980@gmail.com, \\ ari@pkr.ac.id
}

Kata Kunci: Teknik relaksasi genggam jari, nyeri, sectio caesarea

\author{
Keywords: Handheld \\ finger relaxation \\ techniques, pain, \\ ceasarean section
}

\section{Info Artikel}

Tanggal dikirim:30-9-2020

Tanggal direvisi:7-11-2020

Tanggal diterima: 23-1-2021

DOI Artikel:

10.36341/jomis.v5i1.1495

Creative Commons

Attribution-NonCommercialShareAlike 4.0 International License.

\begin{abstract}
ABSTRAK :
Nyeri pasca bedah merupakan salah satu dampak dari persalinan secara sectio caesarea bagi ibu post partum. Nyeri tersebut menimbulkan reaksi fisik dan psikologis pada ibu post partum seperti mobilisasi yang terganggu, malas beraktifitas, sulit tidur, tidak nafsu makan, dan tidak mau merawat bayi. Untuk mengatasi hal tersebut diperlukan cara untuk mengontrol nyeri dengan terapi non-farmakologi, salah satu cara tersebut adalah teknik relaksasi genggam jari. Tujuan penelitian ini adalah untuk mengetahui pengaruh teknik relaksasi genggam jari terhadap intensitas nyeri pada pasien post sectio caesarea di ruang Camar I RSUD Arifin Achmad Provinsi Riau. Jenis penelitian yang digunakan adalah pre-eksperimen dengan rancangan one group pretest - postest design. Penelitian ini dilakukan pada bulan Maret sampai dengan Juni 2018. Populasi dalam penelitian ini adalah seluruh ibu post sectio caesarea di ruang Camar I RSUD Arifin Achmad. Sampel yang diambil adalah sampel minimal yang berjumlah 20 orang. Data dianalisis dengan menggunakan uji wilcoxon. Hasil penelitian menunjukkan rata-rata intensitas nyeri sebelum dilakukan teknik relaksasi genggam jari adalah 6,05 dan sesudah dilakukan teknik relaksasi genggam jari adalah 1,50. Hasil yang didapatkan adalah ada pengaruh teknik relaksasi genggam jari terhadap intensitas nyeri pada pasien post sectio caesarea di ruang Camar I RSUD Arifin Achmad Provinsi Riau dengan $p$ value $0,000(\alpha<0,05)$. Hasil penelitian ini diharapkan dapat digunakan sebagai metode untuk mengurangi nyeri pada pasien post sectio caesarea di RSUD Arifin Achmad Provinsi Riau.
\end{abstract}

\begin{abstract}
:
Cesarean section gives effects to the mother, including post-surgical pain. The pain cause physical and psychological reactions for the postpartum mother such as impaired mobilization, lazy activity, sleeplessness, loss of appetite, and lack of care for the baby. To overcome this, there are need for a way to control pain with nonpharmacological therapy, one of which is handheld finger relaxation technique. The purpose of this study was to determine the effect of handheld relaxation technique on the intensity of pain in post-cesarean section patients in Camar I Room of Arifin Achmad Hospital in Riau Province. This pre-experimental study used one group pretest-posttest design. This study was conducted from March to June 2018. The population was all post-cesarean section mothers with a sample of 20 people. Data were analyzed using the Wilcoxon test. The result showed that the mean pain intensity before handheld relaxation techniques was 6.05 while after was 1.50 . The result was affects of handheld relaxation techniques on the intensity of pain in this study with a $p$ value of $0.000(\alpha<0.05)$. The results of this research can be used as a method for reducing pain in post-cesarean section patients at Arifin Achmad Hospital in Riau Province.
\end{abstract}




\section{PENDAHULUAN}

Periode kritis bagi seorang ibu hamil adalah masa persalinan karena proses yang dilalui merupakan suatu hal yang luar biasa dan membutuhkan perjuangan dari seorang ibu. Penyebab kematian ibu masa persalinan diantaranya terdapat masalah komplikasi atau adanya faktor penyulit yang menjadi faktor resiko sehingga perlu dilakukan tindakan medis sebagai upaya untuk menyelamatkan ibu dan bayi, salah satu diantaranya adalah tindakan bedah sesarea. [1]

Dampak yang dirasakanibupasca persalinan secara sectio caesarea diantaranyaadalah nyeri pasca bedah. Nyeri pasca bedah menimbulkan reaksi fisik dan psikologi pada ibu postpartum seperti mobilisasi terganggu, malas beraktifitas, sulit tidur, tidak nafsu makan dan tidak mau merawat bayi sehingga diperlukan cara untuk mengontrol nyeri agar ibu dapat beradaptasi dengan baik terhadap nyeri post sectio caesarea[2].

Manajemen nyeri mempunyai beberapa tindakan atau prosedur baik secara farmakologis maupun nonfarmakologis. Pemberian analgesik untuk mengurangi atau menghilangkan nyeri merupakan prosedur secara farmakologis sedangkan tindakan non-farmakologis dapat dilakukan dengan cara relaksasi, teknik pernafasan, pergerakan/perubahan posisi, massage, akupressur, terapi panas/dingin, hypnobirthing, musik dan TENS (Transcutaneous Electrical Nerve Stimulation). Tindakan pengontrolan nyeri non-invasif digunakan untuk mendukung terapi farmakologis yang sudah diberikan. Klien dan keluarga dilibatkan dalam merencanakan tindakan non-invasif sehingga klien dan keluarga dapat melakukannya dengan efektif ketika harus menjalani perawatan dirumah [3]

Teknik genggam jari merupakan salah satu pengobatan non-farmakologis yang dapat dilakukan untuk mengurangi nyeri pasca bedah. Beberapa penelitian menunjukkan bahwa relaksasi memberikan pengaruh terhadap penurunan nyeri. Potter \& Perry (2012) mengatakan bahwa relaksasi mampu membuat klien mengontrol diri ketika terjadi rasa tidak nyaman (nyeri), stress fisik dan emosi pada nyeri.

Teknik relaksasi genggam jari merupakan teknik sederhana yang menggabungkan pernafasan dan pegangan pada setiap jari sehingga membantu dalam mengelola emosi dan stres (National Center, 2014). Teknik relaksasi genggam jari membantu tubuh, pikiran dan jiwa untuk mencapai relaksasi. Tubuh yang dalam keadaan relaksasi secara alamiah memicu pengeluaran hormon endorfin. Hormon ini merupakan analgesik alami dari tubuh sehingga nyeri dapat berkurang. Individu dengan endorfin yang banyak merasakan nyeri yang lebih sedikit sedangkan individu dengan sedikit endorfin merasakan nyeri lebih besar[4]

Hasil penelitian Ma'rifah (2015) menunjukkan bahwa teknik relaksasi genggam jari efektif dalam menurunkan nyeri postsectio caesarea. Menurut penelitian Pinandita (2012), teknik relaksasi genggam jari efektif untuk menurunkan intensitas nyeri pada pasien post operasi laparatomi. [5] 


\section{TINJAUAN PUSTAKA}

Teknik sederhana yang menggabungkan pernafasan dan pegangan pada setiap jari sehingga membantu dalam mengelola emosi dan stres yang dikenaldenganteknikrelaksasigenggamjari[ 6].

PenelitianinisejalandenganpenelitianSit i Haniyah, Martyarini Budi Setyawati, tahun 2016 dengan penelitian yang berjudul Efektifitas Teknik Relaksasi Genggam Jari terhadap Nyeri Post Scetio Caesarea di RSUD Ajibarang dinyatakan bahwa nilai rata-rata nyeri pada ibu post sectio caesarea menurun setelah dilakukan teknik relaksasi genggam jari dari 7,09 sebelum dilakukan intervensi menjadi 5,63 setelah dilakukan teknik relaksasi genggam jari.[7]

Penelitianini juga sejalandenganpenelitianIin Pinandita, Ery Purwanti, Bambang Utoyo tahun 2012 dalam Jurnal Ilmiah Kesehatan Keperawatan, Volume 8 yang berjudul Pengaruh

Teknik Relaksasi Genggam Jari terhadap Penurunan Intensitas Nyeri pada Pasien Post Operasi Laparatomi di RSU PKU Muhammadiyah Gombong disimpulkan bahwa teknik relaksasi genggam jari berpengaruh terhadap penurunan intensitas nyeri pada pasien post operasi laparatomi.[8]

Penelitian ini juga sejalandenganyang dilakukan oleh Puji Astutik tahun 2017 tentang pengaruh Relaksasi Genggam Jari terhadap Penurunan Nyeri pada Pasien Post Sectio Caesarea di Ruang Delima RSUD Kertosono disimpulkan ada pengaruh relaksasi genggam jari terhadap penurunan nyeri pada pasien post sectio caesarea di ruang Delima RSUD
Kertosono[9]

\section{METODE PENELITIAN}

Penelitian ini bersifat kuantitatif, jenis penelitian pre-eksperimental, dengan desain penelitian one group pre test - post test design. Rancangan ini hanya menggunakan satu kelompok subjek yaitu ibu post sectio caesarea yang dilakukan observasi terhadap intensitas nyeri post operasi sebelum dilakukan perlakuan teknik relaksasi genggam jari, kemudian diobservasi lagi setelah dilakukan intervensi. Hasil dari observasi terhadap intensitas nyeri post sectio caesarea dibandingkan antara sebelum dan setelah perlakuan teknik relaksasi genggam jari.

Populasi dalam penelitian ini adalah seluruh ibu post sectio caesarea di ruang Camar I RSUD Arifin Achmad Provinsi Riau pada bulan Maret sampai dengan Mei 2018 yang berjumlah 57 orang. Pengambilan sampel dilakukan dengan menggunakan purposive sampling dengan kriteria sampel ibu post sectio caesarea yang mampu berkomunikasi dengan baik, dapat bekerjasama dalam tindakan relaksasi genggam jari dan telah mendapatkan analgetik oral dengan jenis yang sama.

Analisa data yang digunakan adalah Univariat dan Bivariat. Analisis bivariat menggunakan uji Wilcoxon 
HASIL DAN PEMBAHASAN

Tabel 1

Distribusi Rata-Rata Intensitas Nyeri Ibu

Post Sectio Caesarea sebelum dan sesudah dilakukan Teknik Relaksasi Genggam Jari di RSUD Arifin Achmad Provinsi Riau

\begin{tabular}{cccccc}
\hline & & & & & Min \\
$\mathbf{N}$ & Kelompo & $\mathbf{N}$ & $\begin{array}{c}\text { Mea } \\
\mathbf{~}\end{array}$ & $\mathbf{~ S D}$ & $\begin{array}{c}\mathbf{M a} \\
\mathbf{x}\end{array}$ \\
& & & & & \\
\hline 1 & Pretest & 2 & 6,05 & 0,51 & $5-7$ \\
2 & Postest & 0 & 1,50 & 0 & $1-2$ \\
& & 2 & & 0,51 & \\
& & 0 & & 3 & \\
\hline
\end{tabular}

Pada tabel 1 dapat dilihat bahwa ratarata intensitas nyeri pada 20 responden ibu post sectio caesarea mengalami penurunan sesudah dilakukan relaksasi genggam jari yaitu dari rata-rata intensitas nyeri 6,05 menjadi 1,50 pada 20 responden ibu post sectio saesarea.

Tabel 2

Pengaruh Teknik Relaksasi Genggam Jari terhadap Intensitas Nyeri pada Ibu Post Sectio Caesarea di RSUD Arifin Achmad Provinsi Riau

\begin{tabular}{ccccc}
\hline No & Kelompok & N & Mean & $\begin{array}{c}\boldsymbol{P} \\
\text { value }\end{array}$ \\
\hline 1 & Pretest & 20 & 6,05 & \\
2 & Postest & 20 & 1,50 & \\
\hline
\end{tabular}

Sebelum dilakukan analisa bivariat terlebih dahulu dilakukan uji normalitas data. Jika data berdistribusi normal dapat dilakukan uji $t$ dependent, dan bila data tidak berdistribusi normal maka dilakukan uji wilcoxon. Pada uji normalitas didapatkan data tidak berdistribusi normal maka analisa bivariat dilakukan dengan uji wilcoxon.

Berdasarkan tabel 2 dapat disimpulkan bahwa nilai asymp.sign (2-tailed) adalah 0,000 lebih kecil dari nilai $\alpha(0,05)$ sehingga dapat disimpulkan terdapat perbedaan signifikan intensitas nyeri pada ibu post sectio caesarea sebelum dan sesudah dilakukan teknik relaksasi genggam jari di ruang Camar I RSUD Arifin Achmad Provinsi Riau.

Emosi yang dapat dikendalikan dan tubuh menjadi rileks merupakan manfaat yang dapat dirasakan dengan teknik relaksasi genggam jari. Perlakuan relaksasi genggam jari akan menghasilkan impuls yang dikirim melalui serabut saraf aferen yang mengakibatkan pintu gerbang tertutup sehingga stimulus nyeri terhambat dan berkurang. Impuls berupa sentuhan, tekanan, genggaman jari pada telapak tangan akan merangsang neuron-neuron substansia gelatinosa inhibitorik menghambat sel transmiter dalam mentransmisikan impuls nyeri ke otak (menutup gerbang). Proses tersebut menyebabkan aktifitas saraf (A dan C) yang bermielin kecil dan tidak bermielin (membawa impuls nyeri post sectio caesarea) tidak dapat menyalurkan impuls nyeri ke otak. Bila tidak ada informasi nyeri yang disampaikan melalui saraf asenden ke otak, maka tidak ada nyeri yang dirasakan[10].

Hasil penelitian yang dilakukan oleh Sulung (2017) tentang Teknik Relaksasi Genggam Jari terhadap Intensitas Nyeri pada Pasien Post Appendiktomi sejalan denagn penelitian ini. Uji hipotesis dilakukan dengan menggunakan uji wilcoxon yang menunjukkan bahwa $p$ value adalah $0,000<$ $\alpha$ 0,05. Hal tersebut menunjukkan ada pengaruh yang positif antara sebelum dan 
sesudah dilakukan relaksasi genggam jari.[11][12]

Penelitian terkait lainnya adalah penelitian yang dilakukan oleh Ma'rifah (2015) yang berjudul Efektifitas Relaksasi Genggam Jari terhadap Penurunan Skala Nyeri pada Pasien Post Sectio Caesarea di RSUD Prof. Dr. Margono Soekardjo Purwokerto. Dalam hal ini, peneliti membandingkan pada 2 kelompok yaitu 15 responden pada kelompok perlakuan dan 15 responden pada kelompok kontrol. Pada kelompok perlakuan setiap responden diberikan teknik relaksasi genggam jari yang bertujuan merelaksasikan dan menurunkan nyeri pasien post sectio caesarea, sedangkan pada kelompok kontrol tidak diberikan teknik relaksasi genggam jari sehingga tidak terjadi penurunan nyeri karena responden tidak mendapatkan rangsangan/stimulus untuk mengurangi nyeri. Hasil penelitian tersebut menunjukkan skala nyeri sesudah diberikan teknik relaksasi genggam jari lebih rendah dibandingkan yang tidak diberikan teknik relaksasi genggam jari, sehingga dapat disimpulkan bahwa teknik relaksasi genggam jari memiliki nilai efektifitas lebih baik dalam menurunkan nyeri post sectio caesarea.[5].

Dengan adanya penurunan nyeri ini membuktikan bahwa teknik relaksasi genggam jari dapat mengurangi rasa nyeri yang dialami pasien. Teknik ini merupakan metode yang dapat dipilih dan mudah untuk diajarkan pada pasien dan keluarga sehingga pasien dapat melaksanakannya secara mandiri dirumah. Teknik relaksasi genggam jari tersebut dapat dilakukan untuk berbagai kondisi nyeri yang dialami pasien. Apabila relaksasi genggam jari dilakukan secara rutin maka hasil yang diharapkan tentu akan lebih baik.

\section{KESIMPULAN}

Terdapat pengaruh yang signifikan pemberian relaksasi genggam jari terhadap intensitas nyeri pada pasien post sectio caesarea di ruang Camar I RSUD Arifin Achmad Provinsi Riau. dengan $p$ value sebesar 0,000 .

\section{DAFTAR PUSTAKA}

[1] Badan Penelitian dan Pengembangan Kesehatan Kemenkes RI, "Riset Kesehatan Dasar," 1998.

[2] M. D. JENSEN and I. M. BOBAK, "HANDBOOK OF MATERNITY CARE," MCN, Am. J. Matern. Nurs., 1980.

[3] S.N. Prasetyo, Konsep dan Proses Keperawatan Nyeri. Yogyakarta: Graha Ilmu, 2010.

[4] B. G. Smeltzer, S. C \& Barre, "Buku ajar keperawatan medikal-bedah Brunner \& Suddarth.," J. Chem. Inf. Model., 2017.

[5] L. Sofiyah, atun raudotul Ma'rifah, and indri heri Susanti, "Pengaruh Teknik Relaksasi Genggam Jari Terhadap Perubahanskala Nyeri Pada Pasien Post Operasi Sectio Caesareadi Rsud Prof. Dr. Margono Soekardjo Purwokerto," STIKes Harapan Bangsa Purwokerto, pp. 64-71, 2016.

[6] "Fingerhold Practice for Managing Emotions \& Stress *," 2014. [Online]. Available:

http://www.nationalcenterdvtraumamh. org/wpcontent/uploads/2012/01/FingerholdPractice-for-Managing-EmotionsStress-Final.pdf. [Accessed: 01-Feb2018]. 
[7] S. Haniyah, M. B. Setyawati, and S. M. Sholikah, "Efektifitas Teknik Relaksasi Genggam Jari Terhadap Nyeri Post Sectio Caesarea Di RSUD Ajibarang," J. STIKes, vol. 1, no. 1, p. 7, 2016.

[8] B. Pinandita, I. Purwanti, E., \& Utoyo, "Jurnal Ilmiah Kesehatan Keperawatan, Volume 8, No. 1, Februari 2012," Jurnah Kesehat. Perawatan, vol. 8, no. 1, pp. 32-43, 2012.

[9] P. Astutik and E. Kurlinawati, "Konsep \& Aplikasi Manajemen Nyeri," Str. J. Ilm. Kesehat., vol. 6, no. 2, pp. 30-37, 2017.

[10] S. . Price, Patofisiologis konsep klinis proses-proses penyakit. Jakarta: EGC, 2014.

[11] N. Sulung and S. D. Rani, "Pengaruh teknik relaksasi genggam jari terhadap penurunan intensitas nyeri pada pasien post operasi laparatomi di Rumah Sakit Umum Daerah (RSUD) Deli Serdang Lubuk Pakam.," J. Endur., vol. 2, no. 3, pp. 397-405, 2017.

[12] E. Windartik, E. V. Yuniarti, and A. Akbar, "Effectiveness of Relaxation Handheld Fingertechnique and Benson Relaxation to the Changes Level of Post Operative Pain Sectio Caesarea in Rsi Sakinah Mojokerto," Int. J. Sci. Res. Manag., vol. 05, no. 09, pp. 7107-7111, 2017. 